\title{
ВПЛИВ ПОХІДНОГО ПІРОЛУ НА МОРФО-ФУНКЦІОНАЛЬНИЙ СТАН СЕЛЕЗІНКИ ЩУРІВ ЗА ЕКСПЕРИМЕНТАЛЬНОГО ЗАПАЛЕННЯ
}

\author{
Савич Ю. В. ${ }^{1}$, Белінська І. В. ${ }^{1}$, Гурняк О. М. ${ }^{1,2}$, \\ Кузнєцова Г. М. ${ }^{1}$, Дзюбенко Н. В. ${ }^{1}$, Рибальченко В. К. ${ }^{1}$ \\ ${ }^{1}$ Київський національний університет імені Тараса Шевченка, \\ Київ, Україна \\ ${ }^{2}$ Начіональний медичний університет імені О.О. Богомольияя, \\ Київ, Україна
}

\begin{abstract}
Резюме
Вступ. Через відсутність вибірковості дї та високу загальну токсичність медичних препаратів, які використовуються для лікування виразкового коліту існує потреба як у подальшому пошуку нових сполук, так $i$ в удосконаленні існуючих лікарських форм з метою підвищення їх селективності та безпечності. Тому пошук та дослідження ефективних та малотоксичних таргетних протизапальних препаратів є актуальним.
\end{abstract}

Мета - експериментальне дослідження впливу інгібітору низки протеӥнкіназ похідного піролу MI-1 за різних способів введення на морфо-функціональний стан селезінки щурів за умов експериментального гострого виразкового коліту

Матеріали і методи. Гострий коліт у щурів моделювали одноразовим ректальним введенням 0,5 мл 10 \% розчину очттової кислоти. Через 24 та 48 год після індукиії коліту тваринам вводили розчин похідного піролу (1-(4-Cl-бензил)-3-Cl-4(CF3-феніламіно)-1H-пірол-2,5-діон, MI-1) внутрішньо-очеревинно - у вигляді водного розчину, щуо містить $15 \%$ ДМСО або перорально - у вигляді масляного розчину в ефективній дозі 2,7 мг/кг. На гістологічних препаратах селезінки анлізували стан червоної і білої пульпи (підраховували кількість лімфатичних фолікулів, оцінювали мантійний та маргінальний шари лімфатичних фолікулів, наявність гермінативного ичентру).

Результати. Похідне піролу МІ-1 нормалізує кількість лімфатичних фолікулів у білій пульпі селезінки щурів, кількість яких збільшується майже на $40 \%$ за індукиії гострого виразкового коліту. Такі ефекти переважають за інтрагастрального введення МI-1 порівняно з інтраперитонеальним, за якого відбвається злиття та гіперплазія фолікулів. МI-1 зменшує кровонаповнення синусоїдів, кількість макрофагів, які перевантажені пошкодженими запальним процесом еритроцитами, потовщуе ендотелій стінок судин, стимулює еритропоез (зростає кількість «еритробластичних острівців») $i$ нормалізуе надмірно активований за розвитку коліту 
мегакаріоцитопоез у червоній пульпі селезінки щурів на тлі відновлення епітеліальної вистілки товстої кишки порівняно з групою коліту.

Висновки. Похідне піролу МI-1 за гострого виразкового коліту нормалізує морфофункціональний стан червоної $і$ білої пульпи селезінки, зменшує ступінь ураження товстої кишки, щуо свідчить про його протизапальні властивості та $\epsilon$ перспективним для подальших досліджень його як протизапальної сполуки.

Ключові слова: похідне піролу MI-1, виразковий коліт, селезінка, біла пульпа, лімфатичні фолікули, гермінативні центри, червона пульпа.

Конфлікт інтересів: автори заявляють про відсутність конфлікту інтересів.

Фінансування: дослідження виконано за кошти гранту Фонду фундаментальних досліджень Міністерства освіти і науки України «Новітні гібридні протипухлинні та протизапальні нанокомплекси на основі піролів та фулерену C60: розробка, характеристика, фармакодинаміка та токсикологічні характеристики» (№ 0119U100331).

\title{
INFLUENCE OF DERIVATIVE PYRROLE IN THE MORPHO-FUNCTIONAL STATE OF THE RAT'S SPLEEN IN EXPERIMENTAL INFLAMMATION
}

\author{
Savych Y. ${ }^{1}$, Byelinska I. ${ }^{1}$, Hurniak O. ${ }^{1,2}$, \\ Kuznietsova H. ${ }^{1}$, Dziubenko N. ${ }^{1}$, Rybalchenko V. ${ }^{1}$ \\ ${ }^{1}$ Taras Shevchenko National University of Kyiv, Kyiv, Ukraine \\ ${ }^{2}$ Bogomolets National Medical University, Kyiv, Ukraine
}

\begin{abstract}
Introduction. Insufficient selectivity and high general toxicity of drugs used to treat ulcerative colitis initiates the search for new compounds and to improve existing dosage forms to increase their selectivity and safety. Therefore, the search and study of effective and low-toxic target anti-inflammatory drugs are relevant.

The aim is an experimental study of the effect of multi-kinase inhibitor pyrrole derivative MI-1 at different route administration on the morpho-functional state of the rat spleen under experimental acute ulcerative colitis.

Materials and methods. Acute ulcerative colitis in rats was induced by intrarectal administration of $0.5 \mathrm{ml}$ of $10 \%$ acetic acid. After 24 and 48 hours colitis induction 1 (4-Cl-benzyl)-3-chloro-4-(CF3-phenylamino)-1H-pyrrole-2,5-dione (MI-1) dissolved in water containing $15 \%$ DMSO (final volume $0.1 \mathrm{ml}$ ) or oil was injected intraperitoneal or per as in a dose $2.7 \mathrm{mg} / \mathrm{kg}$. The state of the red and white pulp was analyzed using spleen histological specimen (number of lymphatic follicles, mantle, and marginal layers of lymphatic follicles, the presence of the germinal center were evaluated).
\end{abstract}


Results. The pyrrole derivative MI-1 normalizes the number of lymphatic follicles in the rat spleen white pulp, the number of which is increased by almost $40 \%$ after the induction of acute experimental colitis. Such effects prevail after per os administration of MI-1 in comparison with intraperitoneal, in which fusion and hyperplasia of the follicles occur. MI-1 reduces the sinusoid blood overload, the number of overloaded macrophages by inflammatory damaged erythrocytes, thickening the vascular wall's endothelium, stimulates erythropoiesis (the number of "erythroblastic islets» is increased) and normalizes hyperactivated megakaryocytopoiesis in the spleen red pulp under acute colitis along with the restoration of the colon epithelial lining compared with colitis group.

Conclusions. The pyrrole derivative MI-1 normalizes the morpho-functional state of the red and white pulp of the spleen, reduces the degree of colon damage under acute ulcerative colitis, which indicates its anti-inflammatory properties and is promising for further research as an anti-inflammatory compound.

Keywords: pyrrole derivative MI-1, acute colitis, spleen, white pulp, lymphatic follicles, germinal center, red pulp.

\section{Вступ}

В останні роки значну увагу науковці приділяють вивченню виразкового коліту, як однієї з поширених складних патологій травної системи 3 різною клінічною картиною та діагностичним прогнозом. В Україні у 2013 році зареєстровано 9421 випадків захворювань на виразковий коліт (20,8 на 100000 населення). Відмічається тенденція зростання кількості важких, резистентних до лікування форм запальних захворювань кишечника, ускладнень та оперативних втручань, що спричинює інвалідизацію пацієнтів молодого працездатного віку [1].

Основним принципом лікування виразкового коліту $\epsilon$ зменшення процесів запалення та пригнічення аномальної проліферації клітин при регенерації слизової оболонки. Для цього в медичній практиці застосовують препарати на основі 5-аміносаліцилової кислоти, кортикостероїди, тіопурини, інгібітори кальциневрину та антиінтегрини. Проте ці засоби мають низку побічних ефектів у вигляді: порушень травної, нервової, гемопоетичної та імунної систем [2-5].

Тому на даний час однією з найскладніших медико-біологічних проблем залишається створення нових протизапальних засобів з мінімальним ризиком виникнення побічних ефектів (як миттєвих, так і віддалених). Через відсутність вибірковості дії відомих препаратів, а також високу загальну токсичність існує потреба у подальшому пошуку нових сполук, так і в удосконаленні існуючих лікарських форм з метою підвищення їх селективності та безпечності. Тому пошук та дослідження ефективних та малотоксичних протизапальних препаратів $є$ актуальним. 
Серед них привертають увагу похідні піролу, які були синтезовані співробітниками хімічного факультету Київського національного університету імені Тараса Шевченка [6]. Похідні піролу створювались in silico як конкурентні інгібітори АТФ-звязуючого сайту протеїнкіназ. Інгібування низки протеїнкиназ VEGF R1,2,3, PDK1, FGF-R1, YES, EGF-R(h), Src (h), ZAP70, Syk (h), (дослідження проведені ProQinase GmbH, Germany) одним із похідних піролу 1-(4-Cl-бензил)-3-Cl-4-(CF3-феніламіно)-1Н-пірол-2,5-діон виявляє антинеопластичну активність in vitro та in vivo $[7,8]$. Активація деяких із зазначених протеїнкіназ відбувається при активації і проліферації лейкоцитів, які забезпечують імунну відповідь у разі розвитку запалення [9]. Крім того, зазначені кінази активуються при продукції прозапальних цитокінів лімфоцитами, а також у відповідь на дію активних форм кисню, які продукуються нейтрофілами для знешкодьження патогенів, одночасно пошкоджуючи не уражену запаленням тканину i спричинюють прогресію запального захворювання [10]. Активація захисних реакцій організму на будь-які чинники супроводжується змінами морфо-функціонального стану периферичних органів імуногенезу, зокрема селезінки, яка відіграє важливу роль у підтриманні ланок гуморального і клітинного імунітету. Селезінка реагує на будь-який імунопатологічний процес в організмі, іiі відносять до головних органів імуногенезу і розглядають як бактеріальний фільтр крові, що відіграє провідну роль у боротьбі з інфекцією, бере участь у підтримці імунологічного гомеостазу [11]. Тому, застосування інгібіторів протеїнкіназ для регуляції рівня імунної відповіді і зменшення запалення $є$ перспективним, їх низька токсичність і протизапальні властивості були доведені експериментально на моделі гострого і хронічного холангіту [7, 12]. Тож, метою нашого дослідження є аналіз структурної організації селезінки як периферійного органу імунного захисту при дії похідного піролу, якому притаманна протизапальна активність, на моделі гострого коліту щурів.

\section{Матеріали і методи}

Дослідження проводили на 60 білих безпородних щурах-самицях масою тіла 180-250 г. Щурів утримували в умовах віварію на стандартному харчовому раціоні та водному режимі при нормальному світловому дні.

Гострий коліт відтворювали у щурів-самиць одноразовим ректальним введенням 0,5 мл $10 \%$ розчину оцтової кислоти. Попередньо тваринам очищали товсту кишку шляхом ректального введення 2-3 мл фізіологічного розчину з наступним масажем нижньої частини черева для полегшення випорожнення за 10-15 хв. до введення оцтової кислоти. Через 24 
та 48 год. після індукції коліту тваринам вводили розчин похідного піролу (1(4-Сl-бензил)-3-Cl-4-(CF3-феніламіно)-1Н-пірол-2,5-діон, MI-1) внутрішньоочеревинно (у вигляді водного розчину, що містить $15 \%$ ДМСО) або перорально (у вигляді масляного розчину) у ефективній дозі 2,7 мг/кг.

Експериментальні групи у дослідженні ефектів похідного піролу МI-1 на моделі гострого виразкового коліту: I група - Дослідний контроль $(\mathrm{n}=5)$; II група - Коліт (n=7); III група - Коліт + MI-1 перорально (n=6); IV група - Коліт + MI-1 внутрішньо-очеревинно (n=6).

Введення сполук здійснювали через 2 години після введення оцтової кислоти. Контрольні тварини отримували відповідні розчинники. Щурів виводили з експерименту через 3 доби після індукції коліту.

Всі роботи з піддослідними тваринами проводили з дотриманням вимог статті 26 Закону України «Про захист тварин від жорстокого поводження» (від 21.02.2006р.), «Свропейської конвенції по захисту хребетних тварин, які використовуються з експериментальною та іншою науковою метою» (Страсбург, 1986 р.), а також з дотриманням усіх принципів біоетики та норм біологічної безпеки.

Після розтину тварин виділяли товсту кишку, розтинали ії по лінії прикріплення очеревини, промивали у фізіологічному розчині і аналізували внутрішню поверхню слизової оболонки. Стан слизової оболонки товстої кишки за моделювання коліту оцінювали за 10 бальною шкалою [13]. При оцінці пошкоджень слизової оболонки вважали: 0 - відсутність пошкоджень; 1 - локалізована гіперемія, без виразки; 2 - виразка без гіперемії або потовщення стінки кишки; 3 - виразка із запаленням в одному місці; 4 - два або більше сайтів виразки/запалення; 5 - великі сайти пошкодження (більше 1 см) по всій довжині товстої кишки; 610 пошкодження більше 2 см по всій довжині товстої кишки, де оцінка на 1 бал збільшується по кожному додатковому 1 см ушкодження.

Для морфологічних досліджень брали $1 / 2$ селезінки щура, яку фіксували та обробляли за традиційними гістологічними методами виготовлення гістологічних препаратів.

Гістологічні препарати аналізували на світлооптичному рівні за допомогою мікроскопу Olympus BX-41 (Olympus Europe GmbH, Японія), при збільшеннях: $\times 100, \times 400$. Кольорові мікрофотографії отримували за допомогою цифрової фотокамери Olympus C-5050 Zoom (Olympus Europe $\mathrm{GmbH}$, Японія) та мікроскопа Olympus BX-41 (Olympus Europe $\mathrm{GmbH}$, Японія) при тих же збільшеннях.

Відомо, що зміни цито- та гістологічних характеристик органів i тканин, у тому числі і селезінки, відображають їх структурний i 
функціональний стан, базуючись на візуальному аналізі гістологічних препаратів. Серед органів кровотворення та імунного захисту селезінка знаходиться на шляху току крові і контролює іiі імунний статус. Ця функція забезпечується лімфоїдними структурами, що в сукупності утворюють білу пульпу. У білій пульпі селезінки щурів аналізували стан лімфатичних фолікулів: гермінативного центру, мантійного та маргінального шарів і підраховували кількість лімфатичних фолікулів для оцінювання функціонального стану органу.

У червоній пульпі аналізували стан синусоїдних гемокапілярів, оцінювали кількість макрофагів (забезпечують утилізацію зношених і пошкоджених еритроцитів), плазматичних клітин. Окремо оцінювали інтенсивність мега- і еритропоезу.

Статистичну обробку результатів виконували за допомогою програми SPSS 16,0 для Windows. За результатами тесту Шапіро-Уілка встановлено, що показники крові щурів мають ненормальний розподіл в одній з груп порівняння, тому для оцінки різниці між їх значеннями використовували критерій Крускала-Уолліса для множинних порівнянь 3 подальшим застосуванням непараметричного критерію Манна-Уітні. Різницю вважали вірогідною при $\mathrm{p}<0,05$. У тексті роботи представлено середнє арифметичне (М), та його стандартну похибку ( $\pm \mathrm{m})$ : $\mathrm{M} \pm \mathrm{m}$.

\section{Результати та обговорення}

Селезінка щурів контрольної групи мала типову будову. Добре виражена сполучнотканинна капсула, від якої відходять всередину органу трабекули. Строма органа представлена ретикулярною тканиною, яка $\epsilon$ основою для паренхіми - червоної і білої пульпи. До складу червоної пульпи входять синусоїдні капіляри і селезінкові тяжі. Біла пульпа складається з округлих чи овальних лімфатичних фолікулів і періартеріальних лімфоїдних муфт, що оточують центральну артерію, яка розміщена здебільшого ексцентрично. Центральна частина лімфатичних фолікулів, забарвлена менш інтенсивно, ніж периферична, містить великі і середні лімфоцити, лімфобласти, макрофаги і ретикулярні клітини. Периферична частина лімфатичних фолікулів складається з малих лімфоцитів, що утворюють темний зовнішній контур фолікула, за яким, ще далі від центру, розміщується більш світла зона, заповнена макрофагами. Маннтійна зона, що оточує гермінативний центр, містить невелику кількість макрофагів і плазматичних клітин. Маргінальна зона, представлена малими та великими лімфоцитами, які межують і переходять у червону пульпу (рис. 1 A). 




A-лімфатичний фолікул

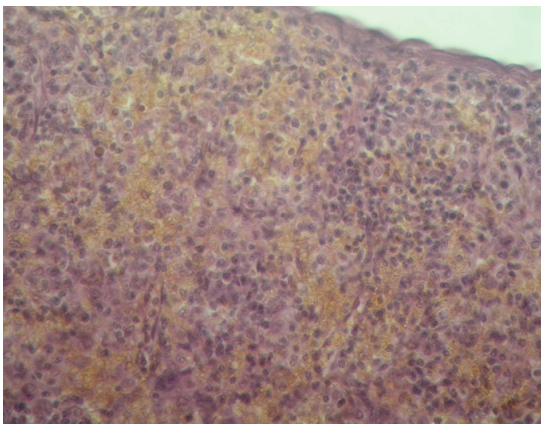

Б-червона пульпа

Рисунок 1. Мікрофотографія зрізу селезінки щурів контрольної групи. Гематоксилін-еозин. $\times 400$

Червона пульпа складається $з$ тривимірної сітки селезінкових тяжів і сітки ретикулярних волокон. Ретикулярна сітка пронизана кровоносними судинами закритого і відкритого типів, які переходять у вени (венозні синусоїди селезінки). Стінки цих синусоїдів підтримуються ретикулярною сіткою. Селезінкові тяжі, або тяжі Більрота, складаються з ретикулярних волокон, ретикулярних клітин, макрофагів пов'язаних з ними. У петлях ретикулярної строми розташовуються макрофаги, лейкоцити, поодинокі мегакаріоцити і гемопоетичні клітини. Стан гемокапілярів контрольної групи селезінки щурів, процеси еритропоезу та мегакаріоцитопоезу у межах норми (рис. 1 Б).

Періартеріальна зона лімфатичних фолікулів займає невелику його частину, представлена переважно Т-лімфоцитами, що потрапляють через гемокапіляри, які відходять від артерії лімфатичного фолікула, та інтердигітуючих клітин. Субмікроскопічні відростки цих клітин витягуються на значну відстань між оточуючими лімфоцитами та тісно контактують 3 ними. Ці клітини адсорбують антигени, що потрапляють сюди 3 кровотоком, та передають Т-лімфоцитам інформацію про стан оточення, стимулюючи їхню бласттрансформацію та проліферацію. Протягом 23 діб активовані Т-лімфоцити залишаються в цій зоні та розмножуються. Згодом, вони мігрують $з$ периартеріальної зони до синусів крайової зони через гемокапіляри. Таким же чином до селезінки потрапляють i В-лімфоцити.

У тварин з експериментально індукованим гострим виразковим колітом у селезінці спостерігається активація функцій як білої, так і червоної 
пульпи порівняно 3 контролем. Червона пульпа селезінки щурів представлена венозними синусами і пульпарними тяжами. У розширених синусоїдах відкритого типу спостерігається надлишкове нерівномірне кровонаповнення. Серед еритроцитів у відкритих синусоїдах зустрічається велика кількість макрофагів, які утилізують пошкоджені запальним процесом еритроцити (рис. 2 А). У червоній пульпі спостерігається активація еритропоезу, що підтверджується збільшенням кількості «еритробластичних острівців», в яких клітини представлені на різних стадіях диференціювання від еритробластів до оксифільних нормобластів (рис. 2 А, Б). Одночасно активується мегакаріцитопоез. Зростає кількість

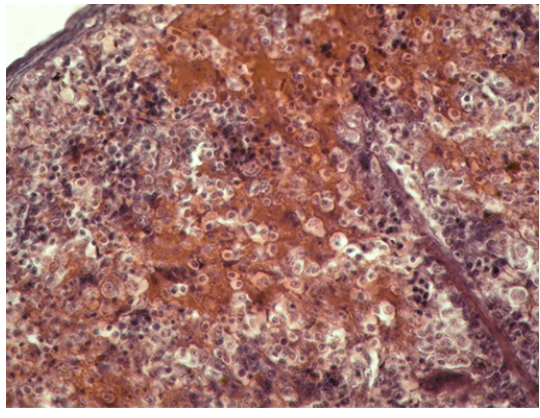

$A$-макрофаги, «еритробластичні острівці» в червоній пульпі

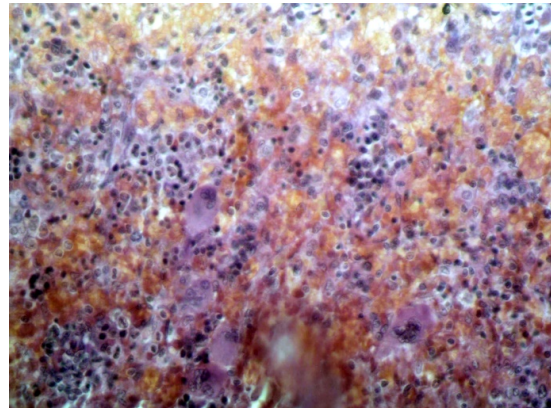

Б - збільшення кількості «еритробластичних острівиів», активачія мегакаріоцитопоезу в червоній пульпі

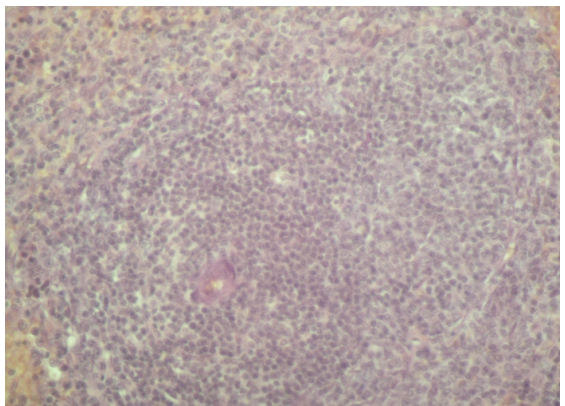

В - збільшена зона ПАЛМ

Рисунок 2. Мікрофотографія зрізу селезінки щурів, група коліт.

Гематоксилін-еозин. $\times 400$ 
як поодиноких мегакаріоцитів, так ї їх кластерів, які представлені мегакаріоцитами на різних стадіях диференціювання (рис. 2 Б). Активація мегакаріоцитопоезу призводить до збільшення продукції тромбоцитів і обумовлює зростання їх кількості у крові. Поява значної кількості мегакаріоцитів у селезінці $є$ компенсаторною реакцією у відповідь на іменопатологічні пошкодження та ознакою розвитку дисбалансу, при якому має місце пошкодження органів імуногенезу, активація в них кровотворення. Також це явище розглядається як феномен перебудови імунної системи у відповідь на активацію антигенами.

Разом 3 тим, активація еритро- та мегакаріоцитопоезу у червоній пульпі селезінки щурів за гострого коліту відбувається у відповідь на крововтрату через пошкодження слизової оболонки товстої кишки для покриття дефіциту еритроцитів у крові і активації гемопоезу. Наслідком крововтрат і пошкоджень запальними процесами еритроцитів $є$ розвиток анемії. Анемії і тромбоцитоз супроводжують шлунково-кишкові захворювання у людей [14, 15].

Синхронно з активацією червоної пульпи активується і біла пульпа селезінки щурів. Виявлено збільшення майже на 40 \% загальної кількості лімфатичних фолікулів (17,5 \pm 0,9 порівняно $312,6 \pm 0,16$ у контролі). Фолікули перебувають на різних стадіях розвитку. Зростає кількість «новоутворених» фолікулів. Одночасно з цим спостерігається різке збільшення у фолікулах гермінативних центрів і розширень зон периартеріальних лімфатичних муфт (ПАЛМ), що свідчить про активацію імунної відповіді (рис. 2 В).

Застосування похідного піролу MI-1 інтрагастрально за експериментально індукованого гострого виразкового коліту нормалізує кровонаповнення синусоїдів у червоній пульпі селезінки порівняно з групою коліту (рис. 3 А). Відбувається потовщення ендотелію стінок судин, що характерно для впливу даної сполуки. Серед еритроцитів у відкритих синусоїдах зустрічаються незначна кількість макрофагів, які утилізують пошкоджені еритроцити, що відображає зниження рівня деструктивних ушкоджень еритроцитів. Активація еритропоезу зберігається, що підтверджується збільшеною кількістю «еритробластичних острівців» (рис. 3 А), спрямована на активне відновлення кількості еритроцитів у крові. Активуючий вплив на еритропоез похідного піролу продемонстровано у наших попередніх дослідженнях [16].

Похідне піролу МI-1 зменшує рівень активації мегакаріоцитопоезу порівняно з групою коліту, зникають кластери цих клітин, наближаючи його до контролю. Дещо збільшена кількість поодиноких мегакаріоцитів 
на різних стадіях диференціювання в паренхімі селезінки $є$ ознакою помірної активації цієї ланки гемопоезу (рис. 3 Б). Зазначені зміни відбуваються на тлі зменшення ступеня пошкодження товстої кишки і відновлення епітеліальної вистілки.

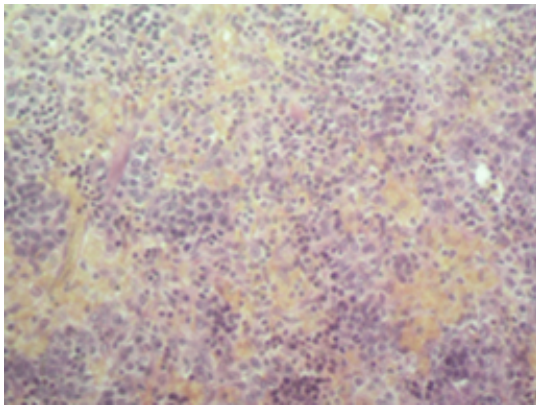

A- збільшення кількості «еритробластичних острівиів» у червоній пульпі

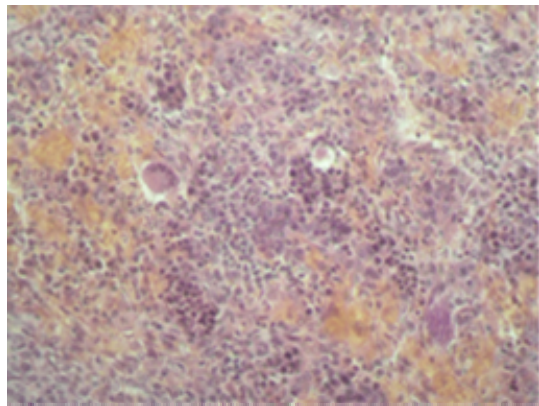

Б-мегакаріоцити та «еритробластичні острівці» в червоній пульпі

Рисунок 3. Мікрофотографія зрізу селезінки щурів при дї похідного піролу MI-1 per. os. на тлі гостро виразкового коліту. Гематоксилін-еозин. $\times 400$

На рівні нормалізації функцій червоної пульпи селезінки щурів спостерігається нормалізація морфо-функціонального стану білої пульпи, про що свідчить зменшення середньої кількості лімфатичних фолікулів на $11 \%$ порівняно 3 колітом $(15,6 \pm 0,18 ; 17,5 \pm 0,9$, відповідно). Проте у окремих тварин середня кількість лімфатичних фолікулів нижча контрольних значень $(9,6 \pm 0,11)$, у інших - зростає до $21 \pm 0,74$, що свідчить про надмірну активацію імунної функції білої пульпи селезінки.

Застосування MI-1 внутрішньо-очеревенно за експериментально індукованого гострого виразкового коліту зменшує активацію функцій як білої, так і червоної пульпи. Кровонаповнення синусоїдів червоної пульпи зменшене порівняно 3 групою коліту, але переважає таке після перорального застосування MI-1 (рис. 4 А). Зменшена кількість макрофагів підтверджує зниження їх навантаження пошкодженими еритроцитами. Занижена кількість перехідних форм мегакаріоцитів в червоній пульпі підтверджує нормалізацію мегакаріоцитопоезу порівняно з групою коліту.

Значна кількість «еритробластичних острівців» спрямована на активне відновлення кількості еритроцитів (рис. 4 А). 


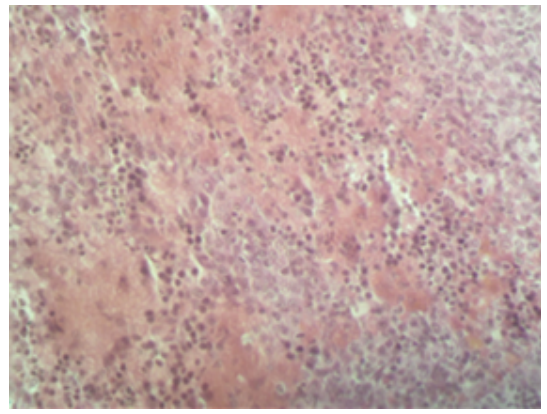

A-червона пульпа



Б - гіперплазія лімфатичних фолікулів

Рисунок 4. Мікрофотографія зрізу селезінки щурів при дії похідного піролу MI-1 інтраперитонеально на фоні гостро виразкового коліту.

Гематоксилін-еозин. $\times 400$

Середня кількість лімфатичних фолікулів переважає контрольні значення (16,2 $\pm 0,21 ; 12,6 \pm 0,16$, відповідно), із тенденцією до зменшення, порівняно з групою Коліт $(17,5 \pm 0,9)$. Відбуваються структурні зміни у фолікулах, а саме їх злиття та гіперплазія (рис. 4 Б.), що аналогічно проявам коліту. Отже, інтраперитонеальне введення похідного піролу МI1 сприяє нормалізації функцій червоної і білої пульпи селезінки, але менш ефективне, порівняно 3 інтрагастральним введенням. Морфо-функціональні зміни в білій пульпі селезінки свідчать про активацію процесів міграції, проліферації та диференціювання імунокомпетентних клітин.

\section{Висновки}

Застосування похідного піролу MI-1 як перорально, так і інтраперитонеально на тлі гострого виразкового коліту зменшує кровонаповнення синусоїдів, потовщує ендотелій стінок судин, стимулює еритропоез i нормалізує надмірно активований за розвитку коліту мегакаріоцитопоез у червоній пульпі селезінки щурів порівняно з групою коліту.

Похідне піролу МI-1 відновлює функціональний стан білої пульпи селезінки наближаючи до норми кількість лімфатичних фолікулів більш ефективно за перорального застосування за умов гострого виразкового коліту.

Гемопоетичні і імунологічні ефекти похідного піролу MI-1 пов'язані 3 інгібуванням низки протеїнкіназ, залучених до розвитку системного запалення, активації імунних клітин, продукції пошкоджуючих активних форм кисню, сприяють зменшенню площі ураження товстої кишки, рівня крововтрати і залученості імунної і гемопоетичної систем до розвитку патологічного процесу. 


\section{Література}

1. Уніфікований клінічний протокол первинної, вторинної (спеціалізованої) та третинної (високоспеціалізованої) медичної допомоги «Запальні захворювання кишечника (хвороба Крона, виразковий коліт)». - Наказ міністерства охорони здоров’я України, 11.02.2016 № 90. Доступно: https://ips.ligazakon.net/ document/ MO Z26054

2. Tripathi K, Feuerstein JD. New developments in ulcerative colitis: latest evidence on management, treatment, and maintenance. Drugs Context. 2019 Apr 29;8:212572. Available from: doi: 10.7573/dic.212572.

3. Siow VS, Bhatt R, Mollen KP. Management of acute severe ulcerative colitis in children. Semin Pediatr Surg. 2017 Dec;26(6):367-372. Available from: doi: 10.1053/j.sempedsurg. 2017.10.006.

4. Jiang Y, Zhao L, Chen Q, Zhou L. Exploring the Mechanism of Berberine Intervention in Ulcerative Colitis from the Perspective of Inflammation and Immunity Based on Systemic Pharmacology. Evid Based Complement Alternat Med. 2021 Jun 9; 2021:9970240. Available from: doi: 10.1155/2021/9970240.

5. Craviotto V, Furfaro F, Loy L, Zilli A, Peyrin-Biroulet L, Fiorino G, et al. Viral infections in inflammatory bowel disease: Tips and tricks for correct management. World J Gastroenterol. 2021 Jul 21;27(27):42764297. Available from:

doi: 10.3748/wjg.v27.i27.4276.

\section{References}

1. Unified clinical protocol of primary, secondary (specialized) and tertiary (highly specialized) medical care «Inflammatory bowel disease (Crohn's disease, ulcerative colitis»). Order of the Ministry of Health of Ukraine, 11.02.2016 № 90. Available: https://ips.ligazakon.net/document/ MOZ26054

2. Tripathi K, Feuerstein JD. New developments in ulcerative colitis: latest evidence on management, treatment, and maintenance. Drugs Context. 2019 Apr 29;8:212572. Available from: doi: 10.7573/dic.212572.

3. Siow VS, Bhatt R, Mollen KP. Management of acute severe ulcerative colitis in children. Semin Pediatr Surg. 2017 Dec;26(6):367-372. Available from: doi: 10.1053/j.sempedsurg. 2017.10.006.

4. Jiang Y, Zhao L, Chen Q, Zhou L. Exploring the Mechanism of Berberine Intervention in Ulcerative Colitis from the Perspective of Inflammation and Immunity Based on Systemic Pharmacology. Evid Based Complement Alternat Med. 2021 Jun 9; 2021:9970240. Available from: doi: 10.1155/2021/9970240.

5. Craviotto V, Furfaro F, Loy L, Zilli A, Peyrin-Biroulet L, Fiorino G, et al. Viral infections in inflammatory bowel disease: Tips and tricks for correct management. World J Gastroenterol. 2021 Jul 21;27(27):42764297. Available from: doi: 10.3748/wjg.v27.i27.4276. 
6. Хиля ОВ, Тихонюк ОI, Мілохов ДС, Воловенко ЮМ, Кузнєцова ГМ, Линчак ОВ, Бєлінська IB, Рибальченко В.К. винахідники; КНУ імені Тараса Шевченка патентовласник. Похідні 4-аміно-3-хлоро1Н-пірол-2,5-діонів, спосіб отримання та застосування їх як засобів протиракової дії. Патент України 121321. 2020 Тра 12. 7. Kuznietsova H, Dziubenko N, Byelinska I, Hurmach V, Bychko A, Lynchak O, et al. Pyrrole derivatives as potential anti-cancer therapeutics: synthesis, mechanisms of action, safety. J Drug Target. 2020; 28(5): 547-563. Available from:

doi: 10.1080/1061186X.2019.1703189

8. Finiuk NS, Ivasechko II, Klyuchivska OY, Kuznietsova H, Rybalchenko VK, Stoika RS. Cytotoxic action of maleimide derivative 1-(4cl-benzyl)-3-chloro-4-(cf3-phenylamino)-1h-pyrrole-2,5-dione toward mammalian tumor cells and its capability to interact with dna. $\mathrm{Ukr}$ Biochem J. 2020;92(4):55-62. Available from: https://doi.org/10.15407/ ubj92.04.055

9. Bai X, Gou X, Cai P, Xu C, Cao L, Zhao Z, et al. Sesamin Enhances Nrf2-Mediated Protective Defense against Oxidative Stress and Inflammation in Colitis via AKT and ERK Activation. Oxid Med Cell Longev. [Internet] 2019 [cited 2019 Aug]; 26;2019:2432416. Available from: https://doi.org/10.1155/2019/2432416

10. Xu Y, Duan C, Kuang Z, Hao Y, Jeffries JL, Lau GW. Pseudomonas aeruginosa pyocyanin activates NRF2-ARE-mediated transcriptional
6. Khilya OV, Tykhoniuk OI, Milokhov DS, Volovenko UM, Kuznietsova HM, Lynchak OV, Byelinska IV, Rybalchenko VK inventors; Taras Shevchenko National University of Kyiv is a patent owner. Derivatives of 4-amino-3-chloro-1H-pyrrole-2,5diones, method for their preparation and use as anticancer agents. Patent of Ukraine 121321. 2020 May 12.

7. Kuznietsova H, Dziubenko N, Byelinska I, Hurmach V, Bychko A, Lynchak O, et al. Pyrrole derivatives as potential anti-cancer therapeutics: synthesis, mechanisms of action, safety. J Drug Target. 2020;28(5): 547-563. Available from: doi: 10.1080/ 1061186X.2019.1703189

8. Finiuk NS, Ivasechko II, Klyuchivska OY, Kuznietsova H, Rybalchenko VK, Stoika RS. Cytotoxic action of maleimide derivative 1-(4cl-benzyl)-3-chloro-4-(cf3-phenylamino)-1h-pyrrole-2,5-dione toward mammalian tumor cells and its capability to interact with dna. Ukr Biochem J. 2020;92(4):55-62. Available from: https://doi.org/10.15407 /ubj92.04.055

9. Bai X, Gou X, Cai P, Xu C, Cao L, Zhao Z, et al. Sesamin Enhances Nrf2-Mediated Protective Defense against Oxidative Stress and Inflammation in Colitis via AKT and ERK Activation. Oxid Med Cell Longev. [Internet] 2019 [cited 2019 Aug]; 26;2019:2432416. Available from: https://doi.org/10.1155/2019/2432416

10. Xu Y, Duan C, Kuang Z, Hao Y, Jeffries JL, Lau GW. Pseudomonas aeruginosa pyocyanin activates NRF2-ARE-mediated transcriptional 
response via the ROS-EGFR-PI3KAKT/MEK-ERK MAP kinase signaling in pulmonary epithelial cells. PLoS One. 2013 Aug 27; 8(8): e72528. Available from:

https://doi.org/10.1371/journal.pone. 0072528

11. Susan A. Elmore Enhanced Histopathology of the Spleen. Toxicol Pathol. 2006;34(5):648-55. Available from:

https://doi.org/10.1080/

01926230600865523

12. Kuznietsova H, Byelinska I, Dziubenko N, Lynchak O, Milokhov D, Khilya O, et al. Suppression of systemic inflammation and signs of acute and chronic cholangitis by multi-kinase inhibitor 1-(4-Cl-benzyl)3-chloro-4-(CF3-phenylamino)-1Hpyrrole-2,5-dione. Mol Cell Biochem. 2021 Aug;476(8):3021-3035. Available from:

https://doi.org/10.1007/s11010-02104144-y

13. Sehirli A, Tathdede E, Yaksel M, Erzik C, Yegen B, Sener G. Protective effects of alfa-lipoic acid against oxidative injury in TNBSinduced colitis. Erciyes Týp Dergisi (Erciyes Medical Journal) 2009; 31(1):015-026. Available from:

https://jag.journalagent.com/

erciyesmedj/pdfs/EMJ_31_1_15_26.pdf

14. Jimenez KM, Gasche C. Management of Iron Deficiency Anaemia in Inflammatory Bowel Disease. Acta Haematol. 2019;142(1):30-36.

Available from: https://doi.org/10.1159/000496728

15. Matowicka-Karna J. Markers of inflammation, activation of blood pla- response via the ROS-EGFR-PI3KAKT/MEK-ERK MAP kinase signaling in pulmonary epithelial cells. PLoS One. 2013 Aug 27; 8(8): e72528. Available from:

https://doi.org/10.1371/journal.pone. 0072528

11. Susan A. Elmore Enhanced Histopathology of the Spleen. Toxicol Pathol. 2006;34(5):648-55. Available from:

https://doi.org/10.1080/

01926230600865523

12. Kuznietsova H, Byelinska I, Dziubenko N, Lynchak O, Milokhov D, Khilya O, et al. Suppression of systemic inflammation and signs of acute and chronic cholangitis by multi-kinase inhibitor 1-(4-Cl-benzyl)3-chloro-4-(CF3-phenylamino)-1Hpyrrole-2,5-dione. Mol Cell Biochem. 2021 Aug;476(8):3021-3035. Available from:

https://doi.org/10.1007/s11010-02104144-y

13. Sehirli A, Tathdede E, Yaksel M, Erzik C, Yegen B, Sener G. Protective effects of alfa-lipoic acid against oxidative injury in TNBSinduced colitis. Erciyes Týp Dergisi (Erciyes Medical Journal) 2009; 31(1):015-026. Available from: https://jag.journalagent.com/ erciyesmedj/pdfs/EMJ_31_1_15_26.pdf

14. Jimenez KM, Gasche C. Management of Iron Deficiency Anaemia in Inflammatory Bowel Disease. Acta Haematol. 2019;142(1):30-36.

Available from: https://doi.org/10.1159/000496728

15. Matowicka-Karna J. Markers of inflammation, activation of blood pla- 
telets and coagulation disorders in inflammatory bowel diseases. Postepy Hig Med Dosw. [Internet] 2016 [cited 2016 Apr]; 13;70:305-12. Available from:

https://phmd.pl/resources/html/articl e/details? id=142346\&language $=$ en

16. Бєлінська IB, Рибальченко ТВ, Цивінська СМ, Рибальченко ВК. Гематологічні ефекти інгібітора протеїнкіназ похідного малеіміду і 5-фторурацилу. Фізіол. журн. 2017; 63(4):37-47.

https://doi.org/10.15407/fz63.04.037

Стаття надійшла 16.08.2021

Контакти: byelinska@ukr.net telets and coagulation disorders in inflammatory bowel diseases. Postepy Hig Med Dosw. [Internet] 2016 [cited 2016 Apr]; 13;70:305-12. Available from: https://phmd.pl/resources/html/article/ details? id=142346\&language $=$ en

16. Byelinska IV, Rybalchenko TV, Tsyvinska SM, Rybalchenko VK. The hematological effects of protein kinase inhibitor maleimide derivative and 5-fluorouracil Fiziol. Zh. 2017; 63(4):37-47. Available from: https://doi.org/10.15407/fz63.04.037 